\title{
Influence of Niobium or Molybdenum Addition on Microstructure and Tensile Properties of Nickel-Chromium Alloys
}

\author{
Marisa Aparecida de Souza ${ }^{1}$, Bárbara de Oliveira Fiorin ${ }^{2}$, Tomaz Manabu Hashimoto ${ }^{1}$, \\ Ana Paula Rosifini ${ }^{1}$, Carlos Angelo Nunes ${ }^{3}$, Carlos Antônio Reis Pereira Baptista ${ }^{3}$ \\ and Alfeu Saraiva Ramos ${ }^{1,2, *}$ \\ 1 Department of Materials and Technology, Campus de Guaratinguetá, São Paulo State University, \\ 12516-410 Guaratinguetá, Brazil; mari_sou@hotmail.com (M.A.d.S.); tmanabu@feg.unesp.br (T.M.H.); \\ rosifini@feg.unesp.br (A.P.R.) \\ 2 Institute of Science and Technology, Federal University of Alfenas, 11999, 37715-400 Poços de Caldas-MG, \\ Brazil; barbarafiorin@hotmail.com \\ 3 Engineering School of Lorena, University of São Paulo, 12602-810 Lorena, SP, Brazil; \\ cnunes@demar.eel.usp.br (C.A.N.); baptista@demar.eel.usp.br (C.A.R.P.B.) \\ * Correspondence: alfeu.ramos@unifal-mg.edu.br; Tel.: +55-35-36974600
}

Received: 26 March 2019; Accepted: 9 May 2019; Published: 22 May 2019

\begin{abstract}
This work discusses on influence of niobium or molybdenum addition on microstructure and tensile properties of NiCr-based dental alloys. In this regard, the $\mathrm{Ni}-24 \mathrm{Cr}-8 \mathrm{Nb}, \mathrm{Ni}-22 \mathrm{Cr}-10 \mathrm{Nb}$ and $\mathrm{Ni}-20 \mathrm{Cr}-12 \mathrm{Nb}$ (wt. \%) alloys produced by arc melting process. To compare the typical $\mathrm{Ni}-22 \mathrm{Cr}-10 \mathrm{Mo}$ dental alloy was also produced. These ternary alloys were analyzed by chemical analyses, $\mathrm{X}$-ray diffraction (XRD), scanning electron microscopy (SEM), electron dispersive spectrometry (EDS), thermogravimetric analysis (TG), Vickers hardness and tensile tests. Although the mass losses of the samples during arc melting, the optical emission spectrometry showed that the initial compositions were kept. The Ni-22Cr-10Mo alloy produced a matrix of $\mathrm{Ni}_{\mathrm{sS}}$ (ss-solid solution), whereas $\mathrm{Ni}_{3} \mathrm{Nb}$ disperse in a $\mathrm{Ni}_{\mathrm{ss}}$ matrix was also identified in $\mathrm{Ni}-\mathrm{Cr}-\mathrm{Nb}$ alloys. Excepting for the $\mathrm{Ni}-22 \mathrm{Cr}-10 \mathrm{Nb}$ alloy with mass gain of $0.23 \%$, the as-cast $\mathrm{Ni}-\mathrm{Cr}$ alloys presented mass gains close to $0.4 \%$ after heating up to $1000{ }^{\circ} \mathrm{C}$ under synthetic airflow. The hardness values, the modulus of elasticity, yield strength and ultimate tensile strength have enhanced, whereas the ductility was reduced with increasing niobium addition of up to $12 \mathrm{wt}$.- $\%$.The $\mathrm{Ni}-22 \mathrm{Cr}-10 \mathrm{Mo}$ alloy presented an intergranular fracture mechanism containing deep dimples and quasi-cleavage planes, whereas the shallow dimples were identified on fracture surface of the as-cast $\mathrm{Nb}$-richer $\mathrm{Ni}-\mathrm{Cr}$ alloys due to the presence of higher $\mathrm{Ni}_{3} \mathrm{Nb}$ amounts.
\end{abstract}

Keywords: microstructure; tensile properties; intermetallics; casting; phase transformation

\section{Introduction}

As-cast nickel-chromium (Ni-Cr) and nickel-chromium-molybdenum (Ni-Cr-Mo) based alloys are applied in dentistry to partial removable prosthesis since 1930 because of their excellent characteristics, such as corrosion resistance and mechanical properties, compared with the more expensive gold-based alloys. Thus, the less expensive and lighter Ni-Cr alloys with high elastic module (170-190 GPa) have been developed for producing metal-ceramic restorations, intra-radicular pins, crowns and removable partial prosthesis [1-3]. In these alloys, the chromium is responsible for the formation of an outer protective oxide layer [4]. Further, the control on the quantities released from dental materials has also been considered for these alloy designs. 
Typical chemical compositions of different commercial Ni-Cr alloys used for metal-ceramic restorations presented the $\mathrm{Cr}$ and Mo contents varying between 18.5-20.4 wt. \% and 4.2-9.5 wt. \%, respectively [5]. Other alloys and traces such as cobalt, iron, zinc and manganese containing up to 2.5, 2.5, 0.65 and $0.1 \mathrm{wt}$. \%, respectively, can be found in these alloys. Studies with Be-free Ni-Cr alloys have been also considered for dental applications [6]. In accordance with the phase diagrams of the nickel-chromium [7] and nickel-molybdenum [8] systems, the adopted chromium and molybdenum amounts in these commercial $\mathrm{Ni}$ alloys are located in regions of Ni solid solutions, respectively. For comparison, the commercial Ni-20Cr-5Mo (wt. \%) alloy with a microstructure based on $\mathrm{Ni}_{\mathrm{ss}}$ (ss-solid solution) was adopted, and its mechanical properties are based mainly on the strengthening solid solution and grain refining mechanisms. However, the use of metal matrix-intermetallic composites can also improve the need flexural strength for dentistry devices [9].

It is well known on the use of niobium as alloying in the new Ti alloys for orthopedic and dentistry devices, since their superior biocompatibility and osseointegration features compared to commercial Ti-6Al-4V alloy [10-12]. In accordance with the phase diagram of the nickel-niobium system [13], the nickel can dissolve up to 4 wt. \% (11 at. \%) $\mathrm{Nb}$ whereas the eutectic reaction $\mathrm{L} \leftrightarrow \mathrm{Ni}+\mathrm{Ni}_{3} \mathrm{Nb}$ at $1216^{\circ} \mathrm{C}$ can happen during solidification of these richer-Ni alloys. The liquidus projection of the $\mathrm{Ni}-\mathrm{Cr}-\mathrm{Nb}$ system indicates the presence of a ternary eutectic reaction $\left[\mathrm{L} \Leftrightarrow \mathrm{NbCr}_{2}\right.$ (high-temperature) + $\mathrm{NbNi}_{3}+\mathrm{Nb}_{6} \mathrm{Ni}_{7}$ ] at $1170{ }^{\circ} \mathrm{C}$ in the rich-Ni region [14].

In this sense, this work reports on the influence of niobium or molybdenum addition in microstructure and tensile properties of nickel-chromium alloys.

\section{Materials and Methods}

In this work, high-purity starting powders of $\mathrm{Ni}, \mathrm{Cr}$ and $\mathrm{Nb}$ were used to prepare the $\mathrm{Ni}-22 \mathrm{Cr}-10 \mathrm{Mo}$, $\mathrm{Ni}-24 \mathrm{Cr}-8 \mathrm{Nb}, \mathrm{Ni}-22 \mathrm{Cr}-10 \mathrm{Nb}$ and $\mathrm{Ni}-20 \mathrm{Cr}-12 \mathrm{Nb}$ alloys (wt. \%) by arc melting process. For comparison, the typical Ni-20Cr-4Mo dental alloy (wt. \%) was also evaluated. In this way, the elemental Ni-Cr-Nb and Ni-Cr-Mo powder mixtures were mixed and then compacted square-section blocks with a length of $55 \mathrm{~mm}$ and a $5 \mathrm{~mm}$ thickness were obtained by axial compaction using 7 ton (approximately $25 \mathrm{MPa}$ ). The Ni-Cr-Mo and Ni-Cr-Nb ingots weighing close to $50 \mathrm{~g}$ were prepared in an arc melting furnace under argon atmosphere using a water-cooled copper hearth (own USP project, Lorena, Brazil), non-consumable tungsten electrode, and gettered by titanium. Five melting steps were carried out for each alloy in order to obtain homogeneous ingots. The mass losses occurred during the melting process were lower than $0.6 \%$, and the nominal compositions were then adopted.

The as-cast $\mathrm{Ni}-24 \mathrm{Cr}-8 \mathrm{Nb}, \mathrm{Ni}-22 \mathrm{Cr}-10 \mathrm{Nb}, \mathrm{Ni}-20 \mathrm{Cr}-12 \mathrm{Nb}$ and $\mathrm{Ni}-22 \mathrm{Cr}-10 \mathrm{Mo}$ (wt. \%) alloys were characterized by chemical analysis, scanning electron microscopy (SEM, Carl Zeiss Microscopy GmbH, Jena, Germany), X-ray diffraction (XRD, Shimadzu Corporation, Kyoto, Japan), electron dispersive spectrometry (EDS, INCA Energy Oxford, Oxfordshire, UK), Vickers hardness and tensile tests (Buehler Global Head Quarters, Lake Bluff, IL, USA) at room temperature.

Chemical analysis of as-cast $\mathrm{Ni}-\mathrm{Cr}-\mathrm{Nb}$ and $\mathrm{Ni}-\mathrm{Cr}-\mathrm{Mo}$ alloys was conducted in an ARL 3460 Optical Emission Spectrometer (OES, Thermo Cientific, Waltham, MA, USA). The total C, S, N and O contents of as-cast $\mathrm{Ni}-\mathrm{Cr}-\mathrm{Nb}$ and $\mathrm{Ni}-\mathrm{Cr}-\mathrm{Mo}$ alloys were measured by combustion analyses in CS-125 and TC-436 LECO analyzers (Leco Corporation, St. Joseph, MI, USA). Conventional metallographic techniques, including the use of silica colloidal suspension for polishing and chemical attack with aqueous acid solution (20 vol. \% $\mathrm{HF}: \mathrm{HNO}_{3}(2: 1)$ ), were adopted in this work.

XRD experiments at room temperature of the monolithic $\mathrm{Ni}-\mathrm{Cr}-\mathrm{Nb}$ and $\mathrm{Ni}-\mathrm{Cr}-\mathrm{Mo}$ alloys were performed in XRD-6000 Shimadzu equipment (Shimadzu Corporation, Kyoto, Japan) using Ni-filtered $\mathrm{Cu}-\mathrm{K} \alpha$ radiation, voltage of $40 \mathrm{kV}$, current of $30 \mathrm{~mA}$, angular range $(2 \theta)$ from $10^{\circ}$ to $80^{\circ}$, angular pass of $0.05^{\circ}$ and counting time per pass of $1 \mathrm{~s}$. Based on the JCPDS database [15] and Powdercell computer program [16], the phases formed in microstructure of as-cast $\mathrm{Ni}-\mathrm{Cr}-\mathrm{Nb}$ and $\mathrm{Ni}-\mathrm{Cr}-\mathrm{Mo}$ alloys were indexed. 
Electron images of as-cast Ni-Cr-Nb and Ni-Cr-Mo alloys were obtained in a Zeiss (LEO) 1450-VP SEM (Carl Zeiss Microscopy GmbH, Jena, Germany) using the secondary electron and back-scattered electron (BSE) detectors. EDS analysis was adopted to measure the amounts of Ni, Cr, N and Mo presents in phases of as-cast $\mathrm{Ni}-\mathrm{Cr}-\mathrm{Nb}$ and $\mathrm{Ni}-\mathrm{Cr}-\mathrm{Mo}$ alloys. At least three measurements per phase were obtained for each sample. The amounts of precipitates in as-cast $\mathrm{Ni}-\mathrm{Cr}-\mathrm{Nb}$ alloys were determined using the Image J computer program [17] from their SEM images.

To determine the oxidation resistance of the $\mathrm{Ni}-\mathrm{Cr}$ alloys evaluated in this work, the thermogravimetric analysis of these as-cast samples was conducted after heating up to $1000{ }^{\circ} \mathrm{C}$ in alumina crucible under synthetic air flow with heating rate of $10{ }^{\circ} \mathrm{C}$ per minute.

Vickers hardness tests of as-cast $\mathrm{Ni}-\mathrm{Cr}-\mathrm{Nb}$ and $\mathrm{Ni}-\mathrm{Cr}$-Mo samples were performed in a Wolpert durometer using $9.81 \mathrm{~N}$ load and loading time of $15 \mathrm{~s}$, according to ASTM E-92 standard [18]. At least eight measurements were obtained for each specimen.

Tensile tests of as-cast $\mathrm{Ni}-\mathrm{Cr}-\mathrm{Nb}$ and $\mathrm{Ni}-\mathrm{Cr}-\mathrm{Mo}$ samples were conducted according to the ASTM E-8M [19] standard in an INSTRON model 8801 servo hydraulic testing machine (Instron Company, Norwood, MA, USA) with load cell of $100 \mathrm{kN}$ capacity. Cylinder specimens with $20 \mathrm{~mm}$ gage length and diameter of $4 \mathrm{~mm}$ were carefully machined. At least three specimens per alloy were tested. Details on their fractured surfaces were obtained by SEM analysis.

\section{Results}

Table 1 shows the $\mathrm{Ni}, \mathrm{Cr}, \mathrm{Nb}$ and Mo contents (wt. \%) of as-cast $\mathrm{Ni}-\mathrm{Cr}-\mathrm{Nb}$ and $\mathrm{Ni}-\mathrm{Cr}-\mathrm{Mo}$ alloys measured by ICP-AES analysis.

Table 1. Elemental contents (wt. \%) measured by an ICP-AES analysis of the Ni-Cr-Nb and Ni-Cr-Mo alloys evaluated in this work.

\begin{tabular}{cccccc}
\hline Element & Ni-20Cr-10Mo & Ni-24Cr-8Nb & Ni-22Cr-10Nb & Ni-20Cr-12Nb & $\begin{array}{c}\text { Commercial } \\
\text { Alloy }\end{array}$ \\
\hline $\mathrm{C}$ & 0.014 & 0.032 & 0.036 & 0.027 & ND \\
$\mathrm{S}$ & 0.011 & 0.012 & 0.015 & 0.012 & ND \\
$\mathrm{N}$ & 0.016 & 0.019 & 0.021 & 0.021 & ND \\
$\mathrm{Al}$ & 0.002 & 0.000 & 0.001 & 0.001 & ND \\
$\mathrm{Si}$ & 0.170 & 0.220 & 0.210 & 0.170 & ND \\
$\mathrm{P}$ & 0.004 & 0.003 & 0.003 & 0.003 & ND \\
$\mathrm{Ti}$ & 0.011 & 0.113 & 0.136 & 0.162 & ND \\
$\mathrm{V}$ & 0.003 & 0.006 & 0.006 & 0.007 & 0.65 \\
$\mathrm{Cr}$ & 21.92 & 24.29 & 22.04 & 20.08 & 70.0 \\
$\mathrm{Mn}$ & 0.010 & 0.030 & 0.010 & 0.010 & ND \\
$\mathrm{Ni}$ & 69.00 & 66.30 & 66.20 & 65.30 & ND \\
$\mathrm{Cu}$ & 0.003 & 0.018 & 0.018 & 0.023 & 11.52 \\
$\mathrm{Nb}$ & 0.010 & 8.090 & 9.840 & 0.006 & 4.2 \\
$\mathrm{Mo}$ & 9.110 & 0.045 & 0.011 & &
\end{tabular}

Table 2 shows the $\mathrm{C}, \mathrm{S}, \mathrm{O}$ and $\mathrm{N}$ contents (wt. \%) of the as-cast $\mathrm{NiCr}$ alloys evaluated in this work, which were determined utilizing either the gas fusion method (nitrogen and oxygen) or the combustion method (carbon and sulfur). 
Table 2. Interstitial contents (wt. \%) measured by LECO combustion analyses of the Ni-Cr-Nb and Ni-Cr-Mo alloys.

\begin{tabular}{ccccc}
\hline Alloy & C (wt. \%) & S (wt. \%) & N (wt. \%) & O (wt. \%) \\
\hline Ni-22Cr-10Mo & 0.020 & 0.020 & 0.016 & 0.099 \\
Ni-20Cr-12Nb & 0.010 & 0.007 & 0.022 & 0.039 \\
Ni-22Cr-10Nb & 0.010 & 0.010 & 0.025 & 0.059 \\
Ni-24Cr-8Nb & 0.020 & 0.099 & 0.019 & 0.054 \\
Commercial & 0.260 & 0.002 & 0.032 & 0.027 \\
\hline
\end{tabular}

XRD patterns of the $\mathrm{Ni}-22 \mathrm{Cr}-10 \mathrm{Mo}$ and $\mathrm{Ni}-20 \mathrm{Cr}-12 \mathrm{Nb}$ alloys as well as the commercial $\mathrm{Ni}-\mathrm{Cr}$ alloy are presented in Figure 1.

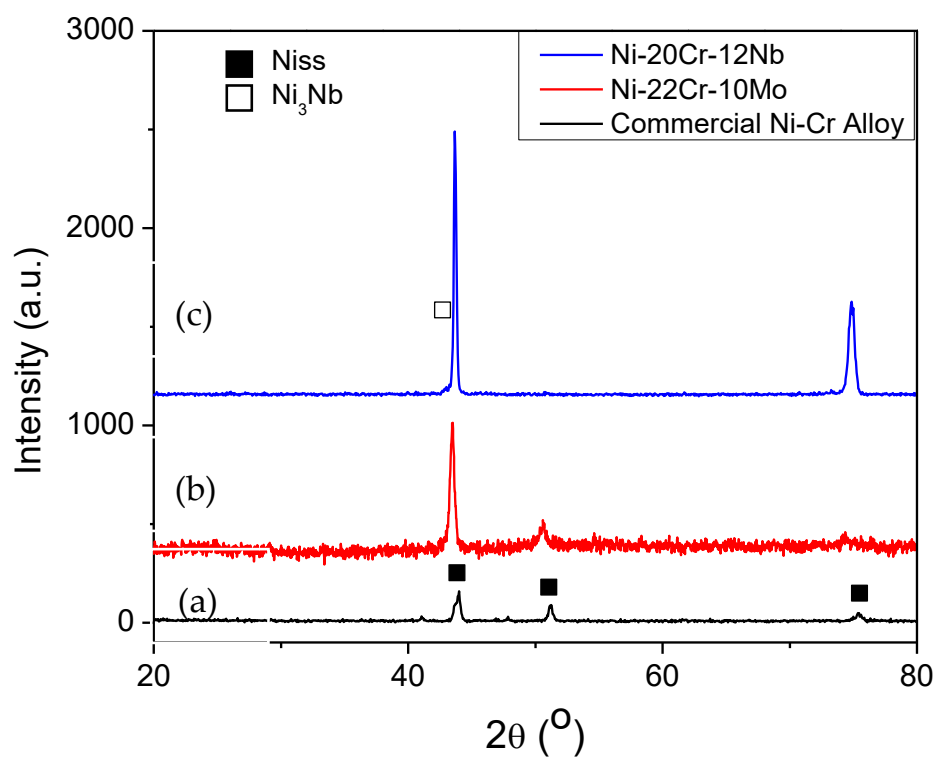

Figure 1. XRD patterns of $\mathrm{Ni}-\mathrm{Cr}$ alloys evaluated in this work: (a) Commercial $\mathrm{Ni}-\mathrm{Cr}$ alloy, (b) Ni-22Cr-10Mo alloy and (c) Ni-20Cr-12Nb alloy.

Figure 2 displays the SEM images of the Ni-22Cr-10Mo alloy as well as the commercial $\mathrm{Ni}-\mathrm{Cr}$ alloy evaluated in this work.
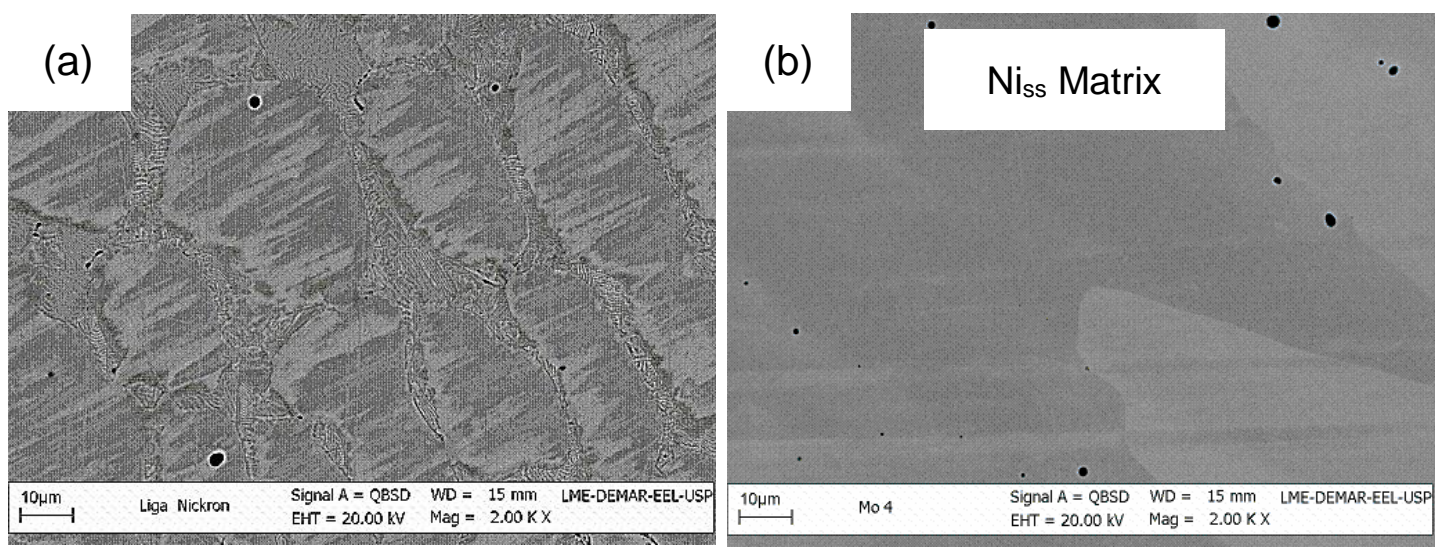

Figure 2. SEM images of the (a) commercial Ni-Cr alloy and (b) as-cast Ni-22Cr-10Mo alloy without a chemical attack.

SEM images of as-cast $\mathrm{Ni}-\mathrm{Cr}-\mathrm{Nb}$ alloys evaluated in this work are presented in Figure 3. 

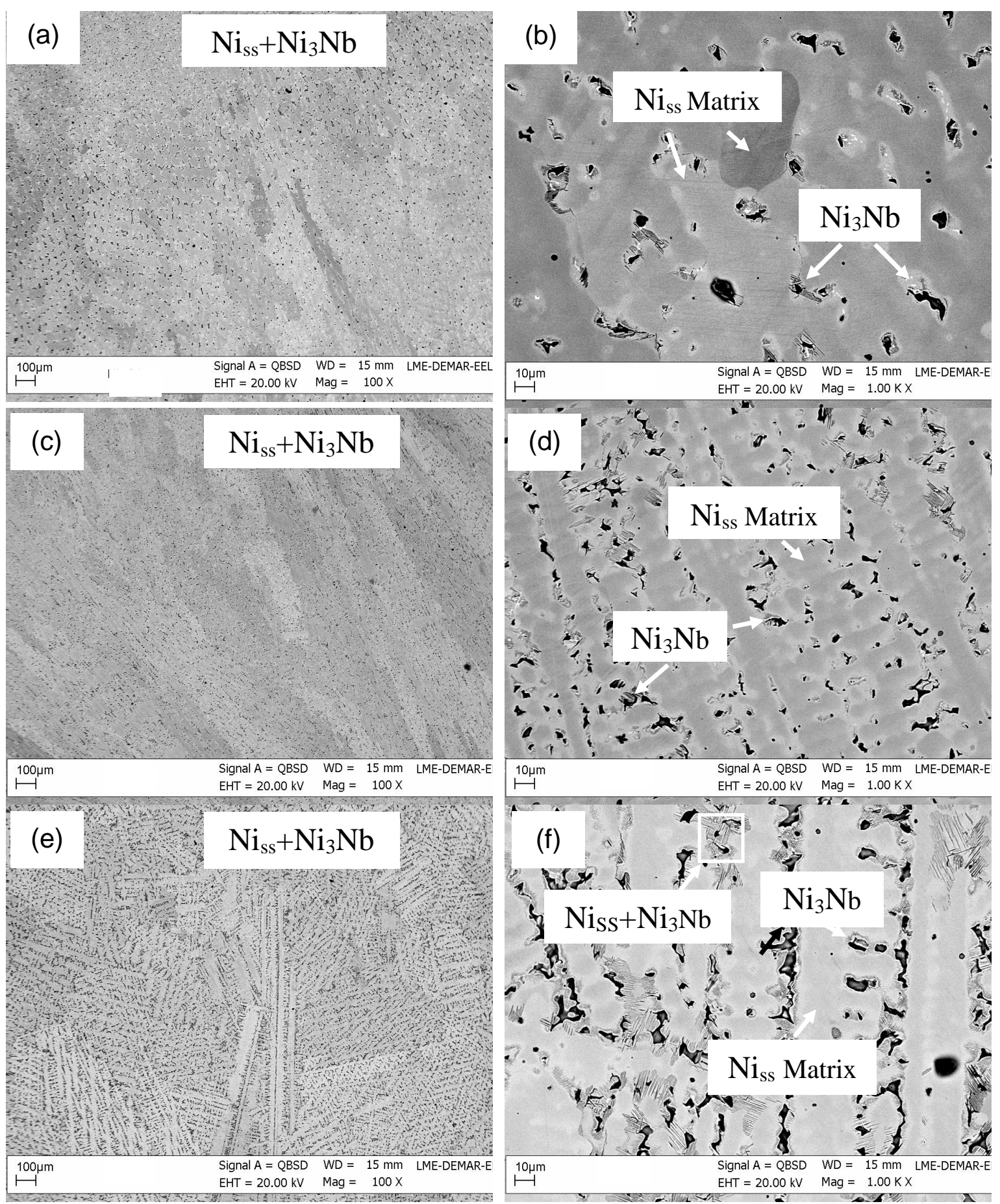

Figure 3. SEM images of the as-cast (a,d) Ni-24Cr-8Nb, (b,e) Ni-22Cr- $10 \mathrm{Nb}$ and $(\mathbf{c}, \mathbf{f}) \mathrm{Ni}-20 \mathrm{Cr}-12 \mathrm{Nb}$ alloys: $(\mathbf{a}, \mathbf{c})$ Without chemical attack and $(\mathbf{b}, \mathbf{d}, \mathbf{f})$ after chemical attack.

The contents (at. \%) of $\mathrm{Ni}, \mathrm{Cr}, \mathrm{Mo}, \mathrm{Nb}$ and other elements measured by EDS analysis of phases formed in the as-cast $\mathrm{Ni}-\mathrm{Cr}-\mathrm{Mo}$ and $\mathrm{Ni}-\mathrm{Cr}-\mathrm{Nb}$ alloys evaluated in this work are presented in Table 3. 
Table 3. The elemental contents (at. \%) measured by electron dispersive spectrometry (EDS) analysis of phases formed in the as-cast $\mathrm{Ni}-\mathrm{Cr}-\mathrm{Nb}$ and $\mathrm{Ni}-\mathrm{Cr}-\mathrm{Mo}$ alloys.

\begin{tabular}{ccccccc}
\hline Alloy & Phase & $\mathbf{N i}$ & $\mathbf{C r}$ & $\mathbf{M o}$ & $\mathbf{N b}$ & Others \\
\hline $\mathbf{N i - 2 2 C r - 1 0 M o}$ & $\mathrm{Ni}_{\mathrm{ss}}$ & $68.5-70.5$ & $24.0-25.5$ & $5.1-6.0$ & - & - \\
$\mathbf{N i}-24 \mathrm{Cr}-\mathbf{8 N b}$ & $\mathrm{Ni}_{\mathrm{ss}}$ & $68.9-69.4$ & $25.4-27.8$ & - & $2.8-5.5$ & - \\
$\mathbf{N i - 2 0 C r - 1 2 N b}$ & $\mathrm{Ni}_{\mathrm{ss}}$ & $70.2-71.1$ & $22.5-25.0$ & - & $3.9-7.1$ & - \\
& $\mathrm{Ni}_{3} \mathrm{Nb}$ & 72.3 & $9.6-10.5$ & - & $17.2-18.1$ & - \\
Commercial & $\mathrm{Ni}_{\mathrm{ss}}$ & $59.5-70.7$ & $22.0-26.7$ & $2.0-4.5$ & - & $\mathrm{Si}(3.6-8.6) ;$ \\
Ni-Cr Alloy & & & & & & $\mathrm{Mn}(0.6-0.7)$ \\
\hline
\end{tabular}

Representative thermogravimetric curves of the as-cast $\mathrm{Ni}-\mathrm{Cr}-\mathrm{Mo}$ and $\mathrm{Ni}-\mathrm{Cr}-\mathrm{Nb}$ alloys evaluated in this work are illustrated in Figure 4.

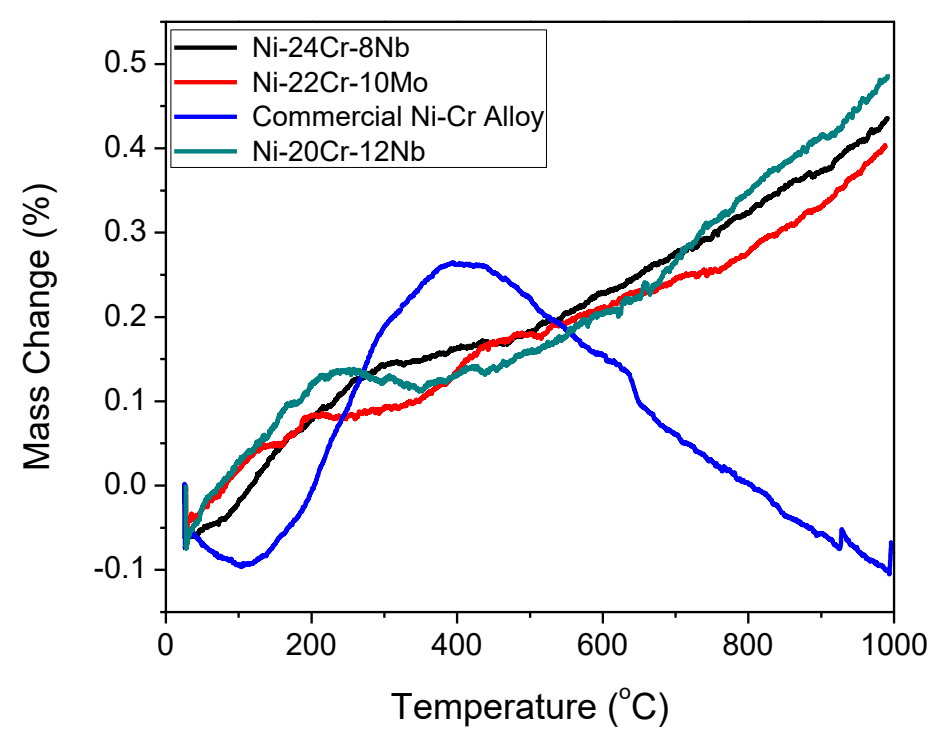

Figure 4. Representative thermogravimetric curves of the commercial $\mathrm{Ni}-\mathrm{Cr}$ alloy, and as-cast $\mathrm{Ni}-\mathrm{Cr}-\mathrm{Nb}$ and Ni-Cr-Mo alloys evaluated in this work.

The Vickers hardness results of as-cast $\mathrm{Ni}-\mathrm{Cr}-\mathrm{Nb}$ and Ni-Cr-Mo alloys investigated in this work are indicated in Table 4.

Table 4. Vickers hardness of the as-cast Ni-Cr-Mo and Ni-Cr-Nb alloys investigated in this work.

\begin{tabular}{cc}
\hline Alloy & Vickers Hardness (HV) \\
\hline $\mathrm{Ni}-22 \mathrm{Cr}-10 \mathrm{Mo}$ & $150.0 \pm 5.3$ \\
$\mathrm{Ni}-24 \mathrm{Cr}-8 \mathrm{Nb}$ & $243.0 \pm 19.8$ \\
$\mathrm{Ni}-22 \mathrm{Cr}-10 \mathrm{Nb}$ & $309.0 \pm 6.7$ \\
$\mathrm{Ni}-20 \mathrm{Cr}-12 \mathrm{Nb}$ & $374.0 \pm 21.1$ \\
Commercial Ni-Cr Alloy & $231.0 \pm 14.6$ \\
\hline
\end{tabular}

The representative tensile $\sigma-\varepsilon$ curves of the as-cast $\mathrm{Ni}-\mathrm{Cr}-\mathrm{Mo}$ and $\mathrm{Ni}-\mathrm{Cr}-\mathrm{Nb}$ alloys are illustrated in Figure 5 whereas their compression mechanical properties are presented in Table 5. 


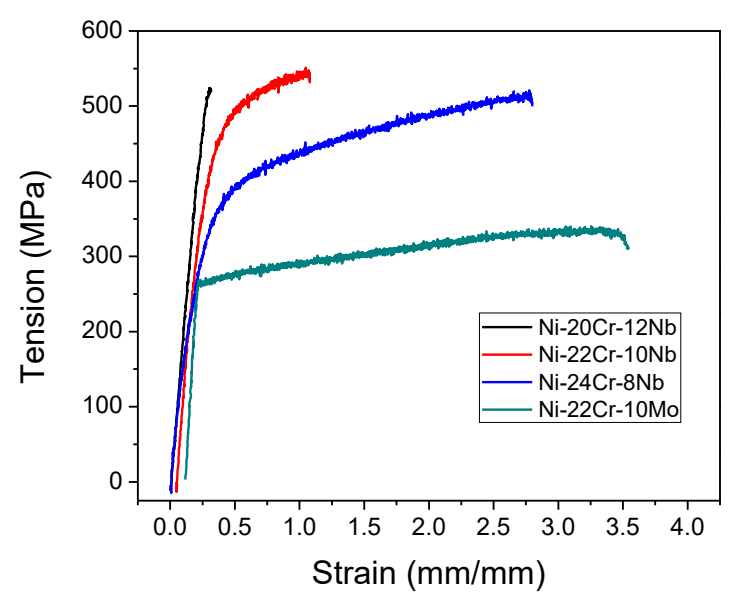

Figure 5. Representative tensile $\sigma-\varepsilon$ curves of the as-cast $\mathrm{Ni}-\mathrm{Cr}-\mathrm{Mo}$ and $\mathrm{Ni}-\mathrm{Cr}-\mathrm{Nb}$ alloys investigated in this work.

Table 5. Tensile mechanical properties of the as-cast $\mathrm{Ni}-\mathrm{Cr}-\mathrm{Mo}$ and $\mathrm{Ni}-\mathrm{Cr}-\mathrm{Nb}$ alloys evaluated in this work.

\begin{tabular}{ccccc}
\hline Alloy & $\begin{array}{c}\text { Yield Strength } \\
\text { (MPa) }\end{array}$ & $\begin{array}{c}\text { Ultimate Tensile } \\
\text { Strength (MPa) }\end{array}$ & $\begin{array}{c}\text { Total Strain } \\
\mathbf{( \% )}\end{array}$ & $\begin{array}{c}\text { Elastic Module } \\
\text { (GPa) }\end{array}$ \\
\hline $\mathrm{Ni}-22 \mathrm{Cr}-10 \mathrm{Mo}$ & $212.4 \pm 46.2$ & $380.6 \pm 36.5$ & $4.2 \pm 0.2$ & $28.9 \pm 16.4$ \\
$\mathrm{Ni}-24 \mathrm{Cr}-8 \mathrm{Nb}$ & $334.2 \pm 22.3$ & $505.3 \pm 22.2$ & $6.5 \pm 0.5$ & $41.4 \pm 0.6$ \\
$\mathrm{Ni}-22 \mathrm{Cr}-10 \mathrm{Nb}$ & $448.4 \pm 48.4$ & $551.3 \pm 51.7$ & $4.5 \pm 0.7$ & $61.0 \pm 5.8$ \\
$\mathrm{Ni}-20 \mathrm{Cr}-12 \mathrm{Nb}$ & $510.5 \pm 81.5$ & $576.5 \pm 133.4$ & $1.8 \pm 0.5$ & $69.5 \pm 18.3$ \\
\hline
\end{tabular}

Details on the fracture surface of the Ni-22Cr-10Mo and $\mathrm{Ni}-20 \mathrm{Cr}-12 \mathrm{Nb}$ alloys after tensile tests are illustrated in Figure 6a,b.
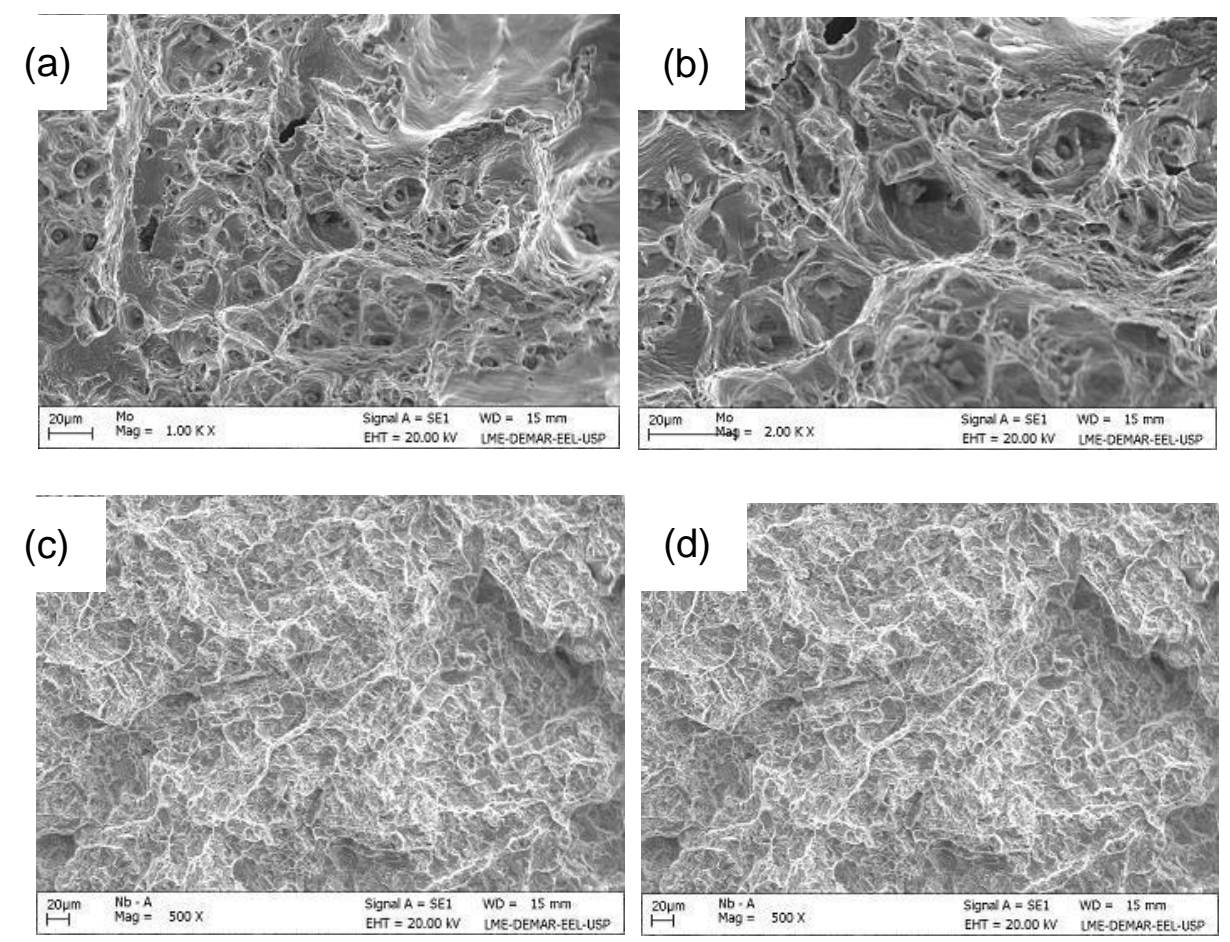

Figure 6. SEM fractographies of the as-cast $(\mathbf{a}, \mathbf{b}) \mathrm{Ni}-22 \mathrm{Cr}-10 \mathrm{Mo}$ and $(\mathbf{c}, \mathbf{d}) \mathrm{Ni}-20 \mathrm{Cr}-12 \mathrm{Nb}$ alloys after tensile tests. 


\section{Discussion}

Chemical analysis by ICP method of the as-cast $\mathrm{Ni}-\mathrm{Cr}-\mathrm{Mo}$ and $\mathrm{Ni}-\mathrm{Cr}-\mathrm{Nb}$ alloys has indicated that the $\mathrm{Cr}, \mathrm{Nb}$ and Mo amounts were kept close to their nominal compositions (see Table 1). The commercial Ni-Cr alloy presented the Ni, Cr and Mo contents of 70, 19.1 and $4.2 \mathrm{wt}$ \%, respectively. Trace of manganese (0.65 wt. \%) was also detected in this commercial alloy.

Similar values of C, S and $\mathrm{N}$ were measured from the combustion gases within the as-cast $\mathrm{Ni}-\mathrm{Cr}-\mathrm{Mo}$ and $\mathrm{Ni}-\mathrm{Cr}-\mathrm{Nb}$ alloys (see Table 2). Despite the route adopted in this work the amount of total oxygen of up to $0.099 \mathrm{wt}$. \% were picked up during arc melting from the compacted elemental powder mixtures only. On contrary, this route has produced alloys with lower $\mathrm{C}$ and $\mathrm{N}$ interstitial amounts than the commercial alloy. Nitrogen contents higher than $0.1 \mathrm{wt}$ \% can contribute to a reduction on the ductility of Ni-based alloys [20]. Similar results were found for a silver-palladium alloy [21]. The commercial alloy had also amounts of $\mathrm{Co}, \mathrm{Fe}, \mathrm{Mn}$ and $\mathrm{Zn}$ of $0.25,0.68,0.65$ and $0.1 \mathrm{wt}$. \%, respectively.

Both the commercial alloy (with 19 wt. \% Cr and 4 wt. \% Mo) and the experimental Ni-22Cr-10Mo alloy presented similar XRD results, as are shown in Figure 1 . In these alloys, the intense $\mathrm{Ni}_{\mathrm{ss}}$ peaks can be observed only, which could be related for X-ray diffraction experiments with monolithic samples. However, these $\mathrm{Ni}_{\mathrm{Ss}}$ peaks have shifted toward the direction of smaller diffraction angles for the Mo-richer alloy, suggesting that the larger molybdenum amount in Ni-22Cr-10Mo alloy is preferentially dissolved into the Ni lattice. Traces of others peaks besides the intense Ni peaks were also identified in XRD patterns of the $\mathrm{Ni}-\mathrm{Cr}-\mathrm{Nb}$ alloys evaluated in this work. Nonetheless, it is very important to note that there are two overlapping peaks between the major diffraction lines of $\mathrm{Ni}, \mathrm{Ni}_{8} \mathrm{Nb}, \mathrm{Ni}_{3} \mathrm{Nb}$ and $\mathrm{Ni}_{6} \mathrm{Nb}_{7}$ [22].

The commercial Ni-Cr alloy evaluated in this work presents primary $\mathrm{Ni}_{\text {ss }}$ grains and a eutectic region located in their grain boundary as is indicated in the SEM micrograph of Figure 2a. It can be also observed the presence of regions with different contrasts into the $\mathrm{Ni}_{\mathrm{ss}}$ grains, which had the contents of $\mathrm{Ni}, \mathrm{Cr}, \mathrm{Mo}, \mathrm{Mn}$ and Si measured by EDS analysis varying between 59.5-70.0, 26.7-22.0, 4.5-2.0, 0.7-0.6 and 8.6-3.8 at. \%, respectively (see Table 3). In this sense, the brighter regions presented the higher $\mathrm{Nb}$ contents. Excepting to the manganese content with 0.9 at. \%, similar elemental values were found in eutectic regions.

Agreeing with the phase diagram of the Ni-Cr-Mo system [23], the microstructure of the as-cast $\mathrm{Ni}-22 \mathrm{Cr}-10 \mathrm{Mo}$ alloy presented in Figure $2 \mathrm{~b}$ has revealed the presence of a homogeneous structure formed by coarse $\mathrm{Ni}_{\mathrm{ss}}$ (ss-solid solution) grains, and the different contrasts observed are relative to their different crystallographic orientations only. No segregation tendency was detected by EDS analysis in these regions in which the $\mathrm{Cr}$ and Mo contents varied between 24.0-25.5 and 5.1-6.0 at. \%, respectively. Some diffusion pores can be also noted in microstructure of this ternary alloy.

The microstructures of the as-cast $\mathrm{Ni}-\mathrm{Cr}-\mathrm{Nb}$ alloys presented in Figure 3 have indicated the same solidification path. Agreeing with the phase diagram of the Ni-Cr-Nb system [14], the solidification is started with the formation of primary $\mathrm{Ni}_{\mathrm{SS}}$ grains followed by simultaneous precipitation of $\mathrm{Ni}_{\mathrm{SS}}$ and $\mathrm{Ni}_{3} \mathrm{Nb}$ for Ni-rich alloys. Comparing with the $\mathrm{Ni}-24 \mathrm{Cr}-8 \mathrm{Nb}$ alloy, it can be noted the presence of larger $\mathrm{Ni}_{3} \mathrm{Nb}$ amounts in microstructure of the $\mathrm{Ni}-20 \mathrm{Cr}-12 \mathrm{Nb}$ alloy. Coherently with the liquidus projection of this ternary system, this alloy containing more eutectic regions is located closer to the $\mathrm{L}+\mathrm{Ni}+$ $\mathrm{Ni}_{3} \mathrm{Nb}$ monovariant line [14]. For the as-cast $\mathrm{Ni}-24 \mathrm{Cr}-8 \mathrm{Nb}$ alloy, the $\mathrm{Ni}_{\mathrm{ss}}$ grains containing different contrasts have presented 25.4-27.8 at. \% $\mathrm{Cr}$ and 2.8-5.5 at. \% Nb, whereas the Nb-rich precipitates containing up to 15 at. \% Nb were also measured by EDS analysis from very fine regions. In addition, it was observed that the brighter $\mathrm{Ni}_{3} \mathrm{Nb}$ precipitates were darker after chemical attack with aqueous acid solution. EDS analysis also indicated that the $\mathrm{Nb}$ contents dissolved into the $\mathrm{Ni}_{\mathrm{ss}}$ lattice were increased in the as-cast $\mathrm{Ni}-20 \mathrm{Cr}-12 \mathrm{Nb}$ alloy, which have varied from 3.9 at. \% to 7.1 at. \% $\mathrm{Nb}$. In this ternary alloy, the coarser $\mathrm{Nb}$-rich precipitates presented $17.2-18.2$ at. \% $\mathrm{Nb}$, indicating to be the $\mathrm{Ni}_{3} \mathrm{Nb}$ phase with highest enthalpy of formation $\left(31 \mathrm{~kJ} \cdot \mathrm{mol}^{-1}\right.$ ) instead to the $\mathrm{Ni}_{8} \mathrm{Nb}$ phase (with $15 \mathrm{~kJ} \cdot \mathrm{mol}^{-1}$ ) containing contents near the 11.1 at. \% $\mathrm{Nb}$ [21]. In this way, these EDS results have confirmed that the traces identified in XRD patterns of as-cast $\mathrm{Ni}-20 \mathrm{Cr}-12 \mathrm{Nb}$ alloy could be associated with the $\mathrm{Ni}_{3} \mathrm{Nb}$ 
phase. According with the Image computer program [17], the SEM images of the as-cast $\mathrm{Ni}-24 \mathrm{Cr}-8 \mathrm{Nb}$, $\mathrm{Ni}-22 \mathrm{Cr}-10 \mathrm{Nb}$ and $\mathrm{Ni}-20 \mathrm{Cr}-12 \mathrm{Nb}$ alloys have indicated the presence of precipitates for $6.3 \%, 6.9 \%$ and $14.4 \%$ in area, respectively.

Remelting operations and thermal cycles are commons for $\mathrm{Ni}-\mathrm{Cr}$ alloys used in dental restorations and high-temperature applications. Similar behavior was noted during heating up to $1000{ }^{\circ} \mathrm{C}$ of $\mathrm{Ni}$-based ternary alloys investigated in this work (see Figure 4). Conversely, the commercial Ni-Cr alloy presented a mass gain of $0.3 \%$ after heating up to $400{ }^{\circ} \mathrm{C}$ followed by a continuous mass loss under heating in synthetic air between $400{ }^{\circ} \mathrm{C}$ and $1000^{\circ} \mathrm{C}$. These facts can be associated with initial oxidation and subsequent reactive evaporation of chromium oxide at high temperatures in the presence of oxygen and/or water vapor, respectively [24]. Thermogravimetric curves of the as-cast Ni-22Cr-10Mo, $\mathrm{Ni}-24 \mathrm{Cr}-8 \mathrm{Nb}, \mathrm{Ni}-22 \mathrm{Cr}-10 \mathrm{Nb}$ and $\mathrm{Ni}-20 \mathrm{Cr}-12 \mathrm{Nb}$ alloys are illustrated in Figure 4, which have indicated mass gains of $0.4,0.43,0.23$ and $0.49 \%$, respectively. Excepting to the $\mathrm{Ni}-22 \mathrm{Cr}-10 \mathrm{Nb}$ alloy, similar oxidation resistance was noted for experimental $\mathrm{Ni}-\mathrm{Cr}$ alloys evaluated in this work.

The Ni-22Cr-10Mo presented lower hardness values than the commercial alloy containing lesser Mo contents, which could be related with its lower interstitial amounts (see Table 4). Similar hardness values were noted between the $\mathrm{Ni}-24 \mathrm{Cr}-8 \mathrm{Nb}$ alloy and commercial $\mathrm{Ni}-\mathrm{Cr}$ alloy. In contrast, the as-cast $\mathrm{Ni}-\mathrm{Cr}$ alloys with $10 \mathrm{wt}$. \% and $12 \mathrm{wt}$. \% $\mathrm{Nb}$ presented higher hardness values than the commercial $\mathrm{Ni}-\mathrm{Cr}$ alloy probably due to the higher $\mathrm{Ni}_{3} \mathrm{Nb}$ amounts in microstructure of these as-cast ternary alloys.

Depending on the composition and processing route, the $\mathrm{Ni}-\mathrm{Cr}$ alloys can present the yield strength and ultimate tensile strength of 260-830 MPa and 440-1200 MPa, respectively [25-28]. The commercial $\mathrm{Ni}-\mathrm{Cr}$ alloy evaluated in this work presented the yield strength (offset $0.2 \%$ ) and ultimate tensile strength of $417 \mathrm{MPa}$ and $550 \mathrm{MPa}$, respectively. Table 5 displays the tensile mechanical properties at room temperature of the as-cast $\mathrm{Ni}-\mathrm{Cr}-\mathrm{Mo}$ and $\mathrm{Ni}-\mathrm{Cr}-\mathrm{Nb}$ alloys investigated in this work. Coherently to the hardness results, the Ni-22Cr-10Mo alloy exhibited the lowest values of yield stress (offset $0.2 \%$ ) and ultimate tensile strength besides the elastic module of 29 GPa close to that related to bone tissues [25-28]. Similarly, the as-cast $\mathrm{Ni}-24 \mathrm{Cr}-8 \mathrm{Nb}$ alloy containing small amounts of $\mathrm{Ni}_{3} \mathrm{Nb}$ also exhibited lower yield strength and ultimate tensile strength. Nevertheless, these tensile properties of as-cast $\mathrm{Ni}-20 \mathrm{Cr}-12 \mathrm{Nb}$ alloy were slightly increased and kept close to those of the commercial $\mathrm{Ni}-\mathrm{Cr}$ alloy. Consequently, the total strain of the $\mathrm{Ni}-24 \mathrm{Cr}-8 \mathrm{Nb}$ alloy was reduced from $6.5 \%$ to $1.8 \%$ in samples of as-cast $\mathrm{Ni}-20 \mathrm{Cr}-12 \mathrm{Nb}$ alloy whereas their elastic module was increased between $41 \mathrm{GPa}$ and $70 \mathrm{GPa}$, respectively. It is well known that the $\mathrm{Ni}_{3} \mathrm{Nb}$ platelets has a detrimental effect on ductility and other mechanical properties that are related to precipitate within the inter-dendritic regions of the as-cast microstructures [29]. In this regard, the development of multicomponent alloys containing the Mo and $\mathrm{Nb}$ additions could produce both the high ductility and mechanical strength for structural applications.

The fracture surface of the as-cast Ni-22Cr-10Mo alloy presented an intergranular fracture mechanism and two different regions constituted with variable dimple sizes, which were associated mainly to crystallography orientation of $\mathrm{Ni}_{\mathrm{ss}}$ grains formed during solidification. Moreover, it was also noted the existence of a small amount of quasi-cleavage planes. Shallow dimples were identified on the fracture surfaces of the as-cast $\mathrm{Ni}-\mathrm{Cr}-\mathrm{Nb}$ alloys, which were less deep with increasing $\mathrm{Ni}_{3} \mathrm{Nb}$ amount as shown in Figure $3 \mathrm{c}, \mathrm{d}$, denoting that the $\mathrm{Ni}_{3} \mathrm{Nb}$ precipitates favored the occurrence of brittle fracture.

\section{Conclusions}

Arc melting successfully produced the low-interstitial Ni-Cr-Nb and Ni-Cr-Mo alloys from elemental powder mixtures.

The values of Vickers hardness, elastic module, yield strength and ultimate tensile strength were enhanced from $243 \mathrm{HV}, 41 \mathrm{GPa}, 334 \mathrm{MPa}$ and $505 \mathrm{MPa}$ to $374 \mathrm{HV}, 70 \mathrm{GPa}, 510 \mathrm{MPa}$ and $576 \mathrm{MPa}$, respectively, with increasing $\mathrm{Nb}$ addition up to $12 \%$ in the alloy composition owing the $\mathrm{Ni}_{3} \mathrm{Nb}$ formation during solidification of $\mathrm{Ni}-\mathrm{Cr}-\mathrm{Nb}$ alloys. 
The Ni-22Cr-10Mo alloy with deep dimples and quasi-cleavage planes on its fracture surface has exhibited intergranular fracture mechanism whereas the shallow dimples were identified on fracture surface of the as-cast $\mathrm{Nb}$-richer $\mathrm{Ni}-\mathrm{Cr}$ alloys due to the presence of higher $\mathrm{Ni}_{3} \mathrm{Nb}$ amounts.

Author Contributions: M.A.d.S. produced the $\mathrm{Ni}-\mathrm{Nb}$ alloys and participated in all stages; B.d.O.F. performed the XRD experiments; T.M.H. participated in all stages; A.P.R. conducted the thermal analysis; C.A.N. obtained SEM images and EDS analysis; C.A.R.P.B. conducted the compression mechanical tests; A.S.R. conceived, participated and coordinate the present work in all stages as well as wrote the paper.

Funding: This research received no external funding.

Acknowledgments: Authors thank to FINEP-, CNPq-, CAPES-, FAPEMIG-, and FAPESP-Brazil by technical supports provided for this work.

Conflicts of Interest: The authors declare no conflict of interest.

\section{References}

1. Bauer, J.R.D.O.; Loguercio, A.D.; Reis, A.; Rodrigues Filho, L.E. Microhardness of Ni-Cr alloys under different casting conditions. Braz. Oral Rev. 2006, 20, 40-46. [CrossRef]

2. Bezzon, O.L.; Mattos, M.G.; Rollo, J.M.; Panzeri, H. Desenvolvimento de uma liga experimental de Ni-Cr para restaurações metalocerâmicas: Ensaios de dureza e resistência mecânica. Rev. Odontol. Univ. São Paulo 1995, 9, 145-149.

3. Chen, W.C.; Teng, F.Y.; Hung, C.C. Characterization of Ni-Cr alloys using different casting techniques and molds. Mater. Sci. Eng. C 2014, 35, 231-238. [CrossRef] [PubMed]

4. Ho, K.H.; Kim, J.H.; Chang, K.; Kwon, J. The role of Cr on oxide formation in Ni-Cr alloys: A theoretical study. Comput. Mater. Sci. 2018, 142, 185-191.

5. Huang, H.H. Surface characterization of passive film on Ni-Cr based dental casting alloys. Biomaterials 2003, 24, 1575-1582. [CrossRef]

6. Bezzon, O.L.; de Mattos, M.D.G.; Ribeiro, R.F.; de Almeida Rollo, J.M. Effect of beryllium on the castability and resistance of ceramometal bonds in nickel-chromium alloys. J. Prosthet. Dent. 1998, 80, 5-570. [CrossRef]

7. Turchi, P.; Kaufman, L.; Liu, Z.K. Modeling of Ni-Cr-Mo based alloys: Part I—Phase Stability. Calphad 2006, 30, 70-87. [CrossRef]

8. Franke, P.; Neuschütz, D. Scientific Group Thermodata Europe (SGTE) Mo-Ni. In Binary Systems. Part 4: Binary Systems from Mn-Mo to Y-Zr; Franke, P., Neuschütz, D., Eds.; Landolt-Börnstein-Group IV Physical Chemistry (Numerical Data and Functional Relationships in Science and Technology); Springer: Berlin/Heidelberg, Germany, 2006; Volume 19B4.

9. Wataha, J.C. Biocompatibility of dental casting alloys. Crit. Rev. Oral Biol. Med. 2002, 87, 351-363.

10. Bania, P.J. Beta titanium alloys and their role in the titanium industry. J. Met. 1994, 46, 16-19. [CrossRef]

11. Rosenstiel, S.F.; Land, M.F.; Fujimoto, J. Prótese Fixa Contemporânea, 3rd ed.; Editora Santos: São Paulo, Brazil, 2002; p. 868.

12. Silva, H.M.; Schneider, S.G.; Neto, C.M. Estudo das propriedades mecânicas das ligas Ti-8Nb-13Zr e Ti-18Nb-13Zr para aplicação como biomaterial. Revista Brasileira de Aplicações de Vácuo 2003, 22, 5-7.

13. Chen, H.; Du, Y.; Xu, H.; Liu, Y.; Schuster, J.C. Experimental investigation of the Nb-Ni phase diagram. J. Mater. Sci. 2005, 40, 6019-6062. [CrossRef]

14. Du, Y.; Liu, S.; Chang, Y.A.; Yang, Y. A thermodynamic modeling of the Cr-Nb-Ni system. Calphad 2005, 29, 140-148. [CrossRef]

15. JCPDS: International Centre for Diffraction Date. Powder Diffraction File (Inorganic Phases), 1st ed.; JCPDS, International Centre for Diffraction Date: Swarthmore, PA, USA, 1988; Volume 2.

16. Kraus, W.; Nolze, G. Powdercell-A program for the representation and manipulation of crystal structures and calculation of the resulting X-ray powder patterns. J. Appl. Crystallogr. 1996, 29, 301-303. [CrossRef]

17. Rasband, W.S. ImageJ; U. S. National Institutes of Health: Bethesda, MD, USA. Available online: https: //imagej.nih.gov/ij/ (accessed on 29 April 2019).

18. ASTM E92-97: Standard Test Method for Vickers Hardness of Metallic Materials; ASTM International: West Conshohocken, PA, USA, 1982; pp. 1-9. 
19. ASTM E8M-00a: Standard Test Methods for Tension Testing of Metallic Materials [Metric]; ASTM International: West Conshohocken, PA, USA, 2001; pp. 1-22.

20. Craig, R.G.; Powers, J.M. Restorative Dentals Materials, 11th ed.; Mosby: St. Louis, MO, USA, 2002.

21. Horasawa, N.; Marek, M. The effect of remolding on corrosion of a silver-palladium alloy. Dent. Mater. 2004, 20, 352-357. [CrossRef]

22. Stachurski, Z.H. Section 3.4.3-X-ray scattering from a-NiNb alloy. In Fundamentals of Amorphous Solids: Structure and Properties; Higher Education Press, Wiley-VCH Verlag GmbH \& Co. KGaA: Weinheim, Germany, 2015; p. 136.

23. American Society for Metals. Alloy Phase Diagrams; ASM Handbook, Metals Park, Ohio: Russell Township, $\mathrm{OH}, \mathrm{USA}, 2016$; Volume 3, pp. 2314-2321.

24. Holcomb, G.R.; Alman, D.E. The effect of manganese additions on the reactive evaporation of chromium in Ni-Cr alloys. Scr. Mater. 2006, 54, 1821-1825. [CrossRef]

25. Bauer, J.R.; Reis, A.; Loguercio, A.D.; Filho, L.E. Resistência à tração e alongamento de ligas de Ni-Cr fundidas sob diferentes condições. RPG Rev. Pós. Grad. 2006, 13, 83-88.

26. Pimenta, A.R.; Diniz, M.G.; Paciornik, S.; Sampaio, C.A.F.; Miranda, M.S.; Paolucci-Pimenta, J.M. Mechanical and Microstructural properties of a nickel-chromium alloy after casting process. RSBO 2012, 9, 17-24.

27. Olivieri, K.A.N.; Neisser, M.P.; Souza, P.C.; Bottino, M.A. Mechanical properties and micro structural analyses of a Ni-Cr alloy cast under different temperatures. Braz. J. Oral Sci. 2004, 3, 414-419.

28. Anusavice, K.J. Phillips: Materiais Dentários, 10th ed.; Guanabara Koogan: Rio de Janeiro, Brazil, 1998.

29. Lass, E.A.; Stoudt, M.R.; Williams, M.E.; Katz, M.B.; Levine, L.E.; Phan, T.Q.; Gnaeupel-Herold, T.H.; Ng, D.S. Formation of the $\mathrm{Ni}_{3} \mathrm{Nb} \delta$-Phase in Stress-Relieved Inconel 625 Produced via Laser Powder-Bed Fusion Additive Manufacturing. Metall. Trans. A 2017, 48, 5547-5558. [CrossRef]

(C) 2019 by the authors. Licensee MDPI, Basel, Switzerland. This article is an open access article distributed under the terms and conditions of the Creative Commons Attribution (CC BY) license (http://creativecommons.org/licenses/by/4.0/). 